\title{
An 'appendiceal colic' caused by the Enterobius vermicularis
}

\author{
Jakub Kaczynski, ${ }^{1}$ Joanna Hilton ${ }^{2}$
}

${ }^{1}$ General Surgery Department, Dumfries and Galloway Royal Infirmary, Dumfries, UK ${ }^{2}$ General Surgery Department, Princess of Wales Hospital, Bridgend, UK

\section{Correspondence to} Dr Jakub Kaczynski, jakub.kaczynski@hotmail.co.uk

Accepted 19 March 2014

\section{DESCRIPTION}

A 35-year-old woman presented with a 96-h history of constant right iliac fossa (RIF) pain on movement and coughing. The pain was associated with vomiting and anorexia, but there was no associated change in bowel habit, weight loss or dysuria. At presentation, she was menstruating and her medical history included asthma, but no previous abdominal pain or surgery. The patient was a smoker, but did not consume alcohol and had no family history of note.

On admission, the patient had a temperature of $37.4^{\circ} \mathrm{C}$ but otherwise normal observations, and examination of the cardiovascular and respiratory system was normal. On palpation, the abdomen was soft with percussion tenderness in the RIF, but digital rectal examination was normal. Laboratory tests showed elevated white cell count of $14 \times 10^{9} / \mathrm{L}$ and $\mathrm{C}$ reactive protein of $223 \mathrm{mg} / \mathrm{L}$. Her liver function tests, amylase and electrolytes were normal. Dip stick urine testing revealed a trace of blood, protein and white cell count but no nitrates, and urine $\beta$-human chorionic gonadotropin ( $\beta$-HCG) was negative.

A provisional diagnosis of an acute appendicitis was made, but due to the prolonged duration of presentation a pelvic ultrasound scan (US) was performed to exclude gynaecological pathology prior to surgery. US demonstrated normal ovaries, a retroverted uterus and no free fluid was seen. Therefore, the decision was made to perform a diagnostic laparoscopy.

A general anaesthetic laparoscopy using a threeport technique was performed and the gallbladder, small bowel and colon were normal. In addition, there was no free abdominal fluid and the uterus and ovaries had normal appearance. The appendix was macroscopically normal. However, in view of the above history and raised inflammatory markers the decision to perform an appendicectomy was made.

Two braided Vicryl suture endoloops (polyglactin 910, Ethicon Endoloop Ligature) were applied proximally to the base of the appendix and one endoloop distally. The appendix was divided between the proximal and distal endoloops and a live pinworm (Enterobius vermicularis) was visible (figure 1), which was immediately removed. The appendix was removed in a specimen bag, and further careful inspection revealed no other worms (figure 2). Histology revealed no inflammation or infestation in the appendix. The patient and family received a single dose of mebendazole $100 \mathrm{mg}$. The patient has made an uncomplicated recovery.

Acute appendicitis is the most common abdominal pathology requiring an emergency operation. ${ }^{12}$

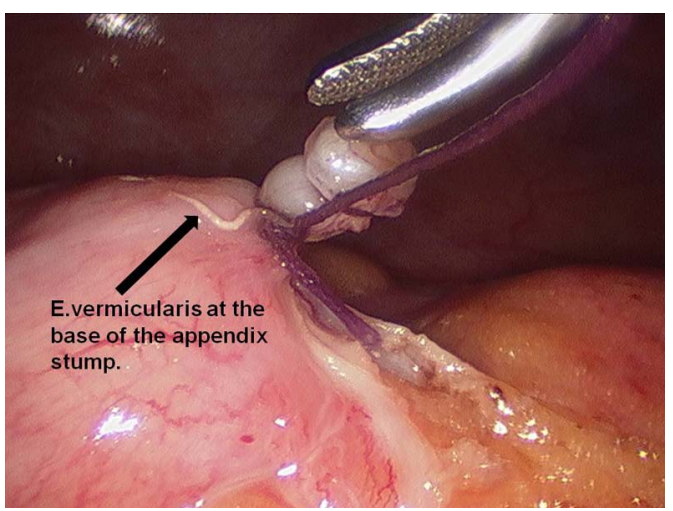

Figure 1 Intraoperative view demonstrating Enterobius vermicularis at the base of the appendix stump.

It may present in any age group, but the peak incidence is in the early adolescents, in boys aged 10-14 years (27.6/10 000 population per year) and in girls aged $15-19$ years (20.5/10 000 population per year). ${ }^{3}$ The reported individual lifetime risk of appendicectomy is $8.6 \%$ for men and $6.7 \%$ for women, respectively. ${ }^{1}$

Although numerous parasites have been implicated in the appendiceal infection, E vermicularis remains the most common parasite worldwide. ${ }^{4-7}$ This is of a particular importance to surgeons as free intraperitoneal contamination may have serious consequences including omentitis, pelvic peritoneal granuloma, salpingitis, chronic pelvic pain and pelvic inflammatory disease. ${ }^{2}{ }^{4}$ In addition, if untreated colitis and perianal abscess have been described. ${ }^{2}$

The histopathological appearances associated with the $E$ vermicularis infestation may vary from lymphoid hyperplasia, chronic inflammatory infiltrate of eosinophils, acute phlegmonous appendicitis and even gangrenous appendicitis with

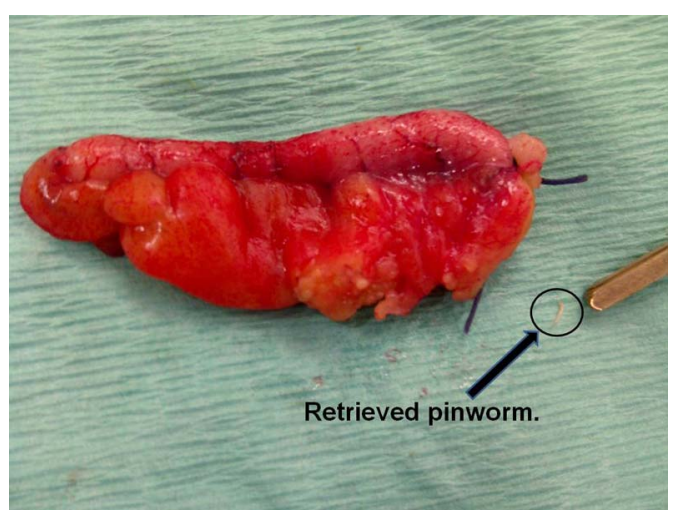

Figure 2 Appendix with the retrieved pinworm. 
perforation. $^{2} 46$ Whereas, in the absence of histological evidence of an inflammation, but with clinical features suggesting an acute appendicitis, some authors use the term of 'appendiceal colic'. ${ }^{2}$ Current evidence does however continue to support the role of Evermicularis in the aetiology of RIF pain and this case highlights that even in young adults pinworm infestation may occur and necessitates meticulous operative technique to prevent contamination. A specimen bag should be used in the abdominal cavity prior to division of the appendix. ${ }^{2}$

Second, a staged division of the appendix should be undertaken with inspection of the appendiceal lumen. ${ }^{2}{ }^{4}$ If worms are visible, then direct retrieval with endoscopic suction or a grasper is indicated. ${ }^{4}$ Additionally, thermal desiccation using endoscopic scissors with supplementary diathermy directly onto

\section{Learning points}

- Pinworm is the commonest parasite that may mimic acute appendicitis.

- Intraoperative macroscopically non-inflamed appendix requires several precautionary steps to be taken in order to minimise peritoneal contamination.

- Pharmacological treatment following appendicectomy is mandatory. the pinworms while still attached to the mucosa of the appendiceal stump may be helpful. ${ }^{2}$ Finally, careful inspection of the port site through which the appendix is delivered is required to avoid contamination. ${ }^{4}$ In the event of spillage, meticulous inspection and endoscopic suction are recommended. ${ }^{4}$

In summary, this case highlights the importance of pinworm infestation in young patients and the necessity for subsequent pharmacological treatment to eradicate the parasite.

Competing interests None.

Patient consent Obtained.

Provenance and peer review Not commissioned; externally peer reviewed.

\section{REFERENCES}

1 Lewis SR, Mahony PJ, Simpson J. Appendicitis. BMJ 2011;343:d5976.

2 Ariyarathenam A, Nachimuthu S, Tang T, et al. Enterobius vermicularis infestation of the appendix and management at the time of laparoscopic appendicectomy: case series and literature review. Int J Surg 2010;8:466-9.

3 Addiss D, Shaffer N, Fowler B, et al. The epidemiology of appendicitis and appendectomy in the United States. Am J Epidemiol 1990;132:910-25.

4 Nordstrand IA, Jayasekera LK. Enterobius vermicularis and clinical appendicitis: worms in the vermiform appendix. ANZ J Surg 2004;74:1024-5.

5 Bhardwaj AK, Sharma P, Sharma A. Falciparum malaria masquerading as appendicitis. BMJ Case Rep 2011;2011:pii: bcr0120113742

6 da Silva DF, da Silva RJ, da Silva MG, et al. Parasitic infection of the appendix as a cause of acute appendicitis. Parasitol Res 2007;102:99-102.

7 Akbulut S, Tas M, Sogutcu N, et al. Unusual histopathological findings in appendectomy specimens: a retrospective analysis and literature review. World J Gastroenterol 2011;17:1961.

Copyright 2014 BMJ Publishing Group. All rights reserved. For permission to reuse any of this content visit http://group.bmj.com/group/rights-licensing/permissions.

BMJ Case Report Fellows may re-use this article for personal use and teaching without any further permission.

Become a Fellow of BMJ Case Reports today and you can:

- Submit as many cases as you like

- Enjoy fast sympathetic peer review and rapid publication of accepted articles

- Access all the published articles

- Re-use any of the published material for personal use and teaching without further permission

For information on Institutional Fellowships contact consortiasales@bmjgroup.com

Visit casereports.bmj.com for more articles like this and to become a Fellow 